\title{
Effects of rubber flooring during the first 2 lactations on production, locomotion, hoof health, immune functions, and stress ${ }^{1}$
}

\author{
S. D. Eicher, ${ }^{* 2}$ D. C. Lay Jr., ${ }^{*}$ J. D. Arthington, $\dagger$ and M. M. Schutz \\ *US Department of Agriculture-Agricultural Research Service (USDA-ARS), Livestock Behavior Research Unit, West Lafayette, IN 47907 \\ †Range Cattle Research and Education Center, University of Florida, Gainesville 32601 \\ ‡Purdue University, Department of Animal Sciences, West Lafayette, IN 47907
}

\section{ABSTRACT}

Some housing systems on dairy farms can result in long-term chronic pain. The effects of acute pain on immunity have been explored, but chronic pain's influence on immune responses is still poorly understood. Therefore, the objective of this research was to determine chronic effects of flooring on immune responses and production in freestall housing for dairy cows. Thirty heifers were studied from before calving as first-calf heifers until d 180 of their second lactation. Treatments were rubber (Kraiburg; Agromatic Inc., Fond du Lac, WI) flooring or concrete with diamond grooves in a freestall barn, each in 2 quadrants of the barn. Heifers entered the treatments after calving, so the system was dynamic and each cow was considered an experimental unit. At the end of the first lactation, cows were housed in a bedded pack barn with pasture access until calving was imminent. At that time, they returned to their assigned treatment, but not necessarily into the same quadrant. Production, reproduction, cortisol, acute-phase proteins, and health data were recorded throughout lactation 1 , locomotion was scored weekly, and hoof scoring and care was conducted on d 60 and 180 of lactations 1 and 2, and quantitative real-time-PCR of blood leukocytes was analyzed in mid lactation of lactation 1. Mature-equivalent milk fat, milk protein, and protein percentages during the first lactation were greater for cows on the rubber flooring. Hoof and leg therapy treatments per cow were fewer for rubber floor-housed cows. Locomotion scores were less for cows housed on rubber during the second lactation. White blood cell counts were less for cows housed on rubber, and caused by greater lymphocyte counts for cows housed on concrete. The possibility of

Received August 9, 2012.

Accepted February 21, 2013.

${ }^{1}$ Mention of trade names or commercial products in this article is solely for the purpose of providing specific information and does not imply recommendation or endorsement by the US Department of Agriculture.

${ }^{2}$ Corresponding author: Susan.Eicher@ars.usda.gov chronic inflammation was substantiated by less IL-1 $\beta$ and more IL-1 receptor antagonists for cows housed on rubber at d 150 in the second lactation. Cortisol and acute-phase proteins did not differ between the treatments. Interferon- $\gamma$, IL-12, the modulator of tissue reconstruction (B-cell-transforming growth factor 1), and pain-modulating neurokinin (tachykinin 1) were not different at $\mathrm{d}$ 105. These data show indicators of chronic inflammation for cows housed on the concrete flooring compared with those housed on rubber. Implications for the use of rubber flooring in freestall barns are broader than just lameness and may affect many aspects of cow physiology and production.

Key words: cow comfort, dairy cow, flooring, immunity

\section{INTRODUCTION}

Cow comfort and dairy lameness are very visible well-being concerns as well as production and economic burdens (Warnick et al., 2001; Cha et al., 2010). Estimates of the percentage of cows that will be affected by lameness during their time in the herd vary, but can approach 50\% (Bicalho et al., 2008). These estimates do not include subclinical cases that may affect cow comfort, behavior, or production in more subtle and undetected ways.

Studies in the United States (Espejo et al., 2006; Espejo and Endres, 2007; Bicalho et al., 2009) have shown that lactation number, BCS, hoof trimming frequency, and stall surface and comfort are associated with lameness. Lameness frequently occurs within 60 d after calving (Booth et al., 2004), as the periparturient hormones and nutritional allocations shift and hooves become more susceptible to disease. Indirect problems such as reduced intake, lower milk yield, or reduced conception rates can arise as a consequence of subclinical or clinical lameness (Calderon and Cook, 2011; Alawneh et al., 2012a). Remedies already viewed as good dairy practice include the use of foot baths for infectious conditions, frequent hoof trimming, reducing damp environments, properly fitted stalls, and earlier 
recognition of problems with the use of technology such as accelerometers (Main et al., 2012).

Housing plays a role in incidence of lameness; grazing systems have fewer lameness incidences than do zerograzing systems and cows housed in straw yards have fewer injuries compared with freestall systems (Haskell et al., 2006). Housing dairy cows on concrete flooring has been shown to be instrumental in the development of lameness (Vanegas et al., 2006). Studies have shown that cows prefer to stand and walk on soft flooring such as soft, textured rubber compared with concrete (Telezhenko et al., 2009) and will stand in bedded cubicles to obtain relief from concrete passageways (Boyle et al., 2007). Therefore, rubber flooring in alleys is another suggested housing change to increase cow comfort and reduce the incidence of lameness. However, the conventional behavioral observations were insufficient for early detection of lameness (Alawneh et al., 2012a,b).

Lameness is just a portion of cow comfort issues related to housing. Alawneh et al. (2012a) showed that response to nociception was a better measure of response to treatment than locomotion scores that is frequently used to determine lameness. However, the relationship between lameness and pain remains complex and obscure. Pain relief with nonsteroidal antiinflammatory drugs modulated hyperalgesia, and may be an aid for chronic or long-term pain (Whay et al., 2005). Here again, measures of nociception were more predictive than locomotion scores. In an effort to obtain a readily available measure of the chronic pain that a cow may be experiencing, alterations in leukocyte gene expression have been tested (Almeida et al., 2007).

Molecular research is focused on changes in pain and tissue repair genes that are associated with clinical and subclinical lameness as early indicators. Some peripheral immune cell responses seem to have indicators of both pain and the repair process (Almeida et al., 2007). Recent data from our laboratory shows that a painrelated gene (tachykinin 1, $\boldsymbol{T A C} \mathbf{C}$ ) as well as a gene involved in cartilage tissue repair (metalloproteinase-13) changed around parturition for cows that had been housed on rubber rather than concrete (O'Driscoll et al., 2009). Therefore, our objectives for this study were to determine the health, cow comfort, hoof health, and leukocyte gene expression of cows housed on rubber flooring compared with those on only concrete.

\section{MATERIALS AND METHODS}

\section{Animals and Experimental Design}

Animal care and use was approved by the Purdue Animal Care and Use Committee (West Lafayette, IN) before the study was initiated. Thirty Holstein heifers were selected for the study within 4 wk of projected calving. Heifers were weighed, locomotion and hooves were scored, and a coccygeal vein blood sample collected into 3-mL EDTA and 10-mL acid citrate dextrose (ACD) vacuum tubes. Twenty-five cows were added to the experiment within the first 2 mo (January and February expected calving dates). Three were removed from the experiment before they calved (1 lame on d 0 , 1 aborted on $\mathrm{d}-30$, and 1 was not on the technicians' calendar and was missed). A second group of 8 was added in August, with 1 with moderate foot problems at the first foot inspection. Therefore, she was deleted from the study.

Heifers remained in bedded-pack prefreshen barns until calving was imminent. Heifers were then moved to maternity stalls with concrete flooring and wood shavings. Heifers were fed by the standard operating protocol for the Purdue Dairy Teaching and Research Unit, which is a prefresh diet before calving, followed by a fresh-cow diet following calving. The feeding routine included once daily feeding, with feed pushed up 5 times daily. Within the freestall area, multiparous cows were used to maintain the herd up to $110 \%$ stocking densities. Following calving, heifers were assigned to freestall housing designated as concrete $(\mathbf{C O N})$ or rubber (RUB) throughout the first lactation. At dry off, cows were returned to the pasture and beddedpack barn until calving was imminent, when they were moved to the calving area. After calving, the cows returned to the same assigned flooring treatment for their second lactation, although not necessarily to the same pen (quadrant).

The freestall barn was arranged as a 4-row barn with drive-through feed lane. Thus, each pen had 2 rows of freestalls arrange in a tail-to-tail fashion, with one row of stalls facing the outside wall and a 3.05-m litter alley between the freestalls. The Kraiburg rubber flooring (Agromatic Inc., Fond du Lac, WI) was installed to extend from the feed bunk $3.66 \mathrm{~m}$ to the face of the inside row of freestalls to cover the entire width of the feed access alley, but not in the litter alley between the rows of freestalls. The rubber flooring was also installed in front of the water troughs that were in the cross alleys. The rubber flooring was 24-mm thick with a grip profile surface (Kraiburg Kura P; Agromatic Inc.). The German Agricultural Society Test Centre for Agricultural Machinery (DLG Test Report 5405: http:// www.dlg-test.de/pbdocs/5405_e.pdf; accessed October 15,2012 ) reported a penetration depth of $3.5 \mathrm{~mm}$ of a steel foot at a force of $2,000 \mathrm{~N}$. This translates to 7.84 to $9.8 \mathrm{~mm}$ for cows weighing 454 to $568 \mathrm{~kg}$. Slip resistance was described as good at a speed of $20 \mathrm{~mm} / \mathrm{s}$ on both dry and wet surfaces. The concrete flooring was a 
10-cm diamond grooved floor throughout the freestall area. The concrete flooring was in good condition and not slippery. Two water troughs were available within each identical quadrant $(70-\mathrm{cm}$ wide, located in a $2.5-\mathrm{m}$ cross alley).

Production and health data were recorded throughout both lactations. Blood samples were collected and locomotion was scored weekly until d 180 of lactation 1 and at $\mathrm{d}-30$ before the second lactation blood collection and locomotion scoring were reinitiated, and then weekly after calving until d 180 of lactation 2. Hoof scoring and care was conducted on d 60 and 180 of lactations 1 and 2 .

\section{Production Variables}

Calving Scores. Calving difficulty scores were assigned on a linear scale by herd personnel in retrospect following the birth of the heifer's first calf. Scores were assigned on a scale from 1 to 5 , with $1=$ unobserved or no difficulty, $2=$ slight difficulty, $3=$ moderate difficulty possibly with manual assistance, $4=$ difficulty with mechanical assistance required, $5=$ extreme difficulty with hard pull or caesarian section.

Fertility. The number of inseminations and number of days from calving to successful breeding were recorded following first calving. The date of successful insemination was verified by pregnancy diagnosis and by comparison to subsequent calving date for cows remaining in the herd. Pregnancy was determined by manual pregnancy checks by a veterinary theriogenologist (board certified) at weekly herd visits, so that cows were checked, on average, at $32 \mathrm{~d}$ ( 28 to $35 \mathrm{~d}$ after insemination) by ultrasound if they had not been detected in estrus. Cows were checked again at about $90 \mathrm{~d}$ after breeding and again at dry off. None were removed in the second lactation for reproductive failures.

Milk Production and Analysis. Milk, fat, and protein yields were recorded by the DHI supervisor monthly; and mature-equivalent (MEQ) milk, MEQ fat, and MEQ protein records were obtained from Dairy Records Management Service (DRMS, Raleigh, NC). Mature-equivalent records are adjusted for stage of lactation, age at calving, season of calving by geographic region, and days open during the previous lactation. Lactation estimates of fat and protein percentages were also obtained. Persistency of the lactation curve was also obtained from DRMS as an index with base of 100 , indicating whether the cow's lactation was more or less persistent than average.

Health. Records of injuries, diagnosed diseases, and culling were kept for the duration of the experiment. Disease diagnosis was determined by the farm managers and herd veterinarian.
$S C \boldsymbol{C}$. Somatic cell counts were converted to logarithm base 2 linear scores (SCS) for each monthly test day. Lactation average of linear SCS was obtained from DRMS.

Herd Life and Culling. Herd life was measured as the number of days the heifer remained in the herd (until dead or sold) following calving. Culling differences were determined by recording whether the cow was still in the study at d 180 of the second lactation. Reasons for the cull were not recorded. Chi-squared analysis was used to determine the probability of differences between the treatments.

\section{Hoof Health and Locomotion}

Hoof Scores. Hoof scoring was performed by a single, trained technician with the assistance of 2 hoof trimmers who routinely serve the dairy. These 2 trimmers were used because of the consistency of their work. Hooves were scored according to Shearer et al. (2004). Hooves were scored using 12 areas to identify the affected location on the claw; the affected foot and claw were identified using numbers 1 to 8 , giving a unique number to the lateral and medial claw on each foot. The following conditions were identified: sole and white line hemorrhages, sole separation, sole ulcer, toe ulcer, white line, heel horn, papillomatous digital dermatitis, and foot rot. Additionally, a 3-number system identified whether the condition was minor (= 1 ), with no blood visible and the condition contained to 1 tissue layer; moderate $(=2)$, crossing more than 1 tissue layer; or severe $(=3)$, with extensive tissue damage.

Locomotion Scores. Locomotion scoring was a modification of that used by O'Callaghan et al. (2003). Spine scores were given a score from 1 to 5 using the definitions of Sprecher et al. (1997). Tracking, head level, and foot rotation were also scored 1 to 5 , with 1 being the optimum scores (O'Callaghan et al., 2003). A tracking score of 5 involved hoof or leg contact with another leg while walking. A foot rotation was scored 5 when feet were moved outside the width of the body in a paddle movement. Head levels corresponded to the back arch described by Sprecher et al. (1997); as the back arched, the head was lower. Speed was determined as the time that it took the cow to cross a 9-m designated segment of the alley when returning from the parlor. A computerized laser system was used to record speed over that distance. Cattle were held in a pen as they returned from the parlor. Each cow or heifer was singly removed from the pen and scored by 2 observers as she moved along a rubber covered alley. All cows were accustomed to walking on rubber moving to and from the parlor. Observer agreement was $>90 \%$ before 
initiation of the experiment and as tested periodically throughout the experiments.

\section{Physiology and Immunology}

Blood Analysis. Blood was collected from coccygeal vein into one $3-\mathrm{mL}$ EDTA tube and one $10-\mathrm{mL}$ ACD vacuum tube. The EDTA blood samples were used for cortisol and hematology analysis. The ACD blood samples were used for acute-phase protein analysis (haptoglobin, ceruloplasmin, and fibrinogen) and mRNA extraction PCR analysis.

Cortisol. Plasma was stored at $-20^{\circ} \mathrm{C}$ until later analysis for total cortisol concentration. Cortisol concentrations $(\mathrm{ng} / \mathrm{mL})$ were determined on duplicate samples using standard RIA double antibody kits (DiaSorin Inc. Stillwater, MN). Samples were rerun if duplicates differed by more than $5 \%$. The interassay coefficient of variation was $9.9 \%$ and the intraassay coefficient of variation was $8.5 \%$.

Hematology. Five-part differential blood analysis was determined from the EDTA blood samples by using a Hemavet hematology analyzer (Drew Scientific Inc., Waterbury, CT). However, only total white blood cell (WBC) counts, granulocyte counts and percentages, peripheral blood mononuclear cell (lymphocytes and monocytes) counts and percentages, and hematocrit were analyzed.

Acute-Phase Proteins. Single samples of plasma fibrinogen were analyzed by Idexx Laboratories Inc. (Westbrook, MA; QBC Autoread hematology analyzer). Duplicate samples of plasma haptoglobin concentrations were determined by measuring haptoglobinhemoglobin complexing by the estimation of differences in peroxidase activity (Makimura and Suzuki, 1982). Results are expressed as arbitrary units resulting from the absorption reading $\times 100$ at $450 \mathrm{~nm}$. Interassay and intraassay coefficients of variation were 2.60 and $3.42 \%$, respectively. Duplicate samples of plasma were used to determine ceruloplasmin oxidase activity, which was measured by using the colorimetric procedures described by Demetriou et al. (1974). Ceruloplasmin concentrations were expressed as milligrams per deciliter, as described by King (1965). Interassay and intraassay coefficients of variation were 2.47 and $2.74 \%$, respectively.

Reverse Transcription and PCR. Messenger RNA was purified from 1-mL aliquots of leukocytes that had been stored in RNAlater using the Qiagen RNA blood kit (Qiagen Inc., Valencia, CA). The extracted mRNA samples were quantified for purity by 260/280 ratios using GeneQuant pro RNA/DNA Calculator (Amersham Pharmacia Biotech, Cambridge, UK); ratios of 1.8 to 2.0 were used. The quality of samples for real-time quantitative reverse-transcription PCR (qRT-PCR) analysis was determined by the Purdue Core Genomics Laboratory (West Lafayette, IN) using a bioanalyzer (NanoDrop 8000; Thermo Scientific, Wilmington, DE). For subsequent PCR analysis, samples were reverse transcribed using TaqMan reverse-transcription reagents (Applied Biosystems Inc., Foster City, CA) at a volume of $100 \mu \mathrm{L}$, containing $50 \mathrm{U}$ of MultiScribe reverse transcriptase $/ \mu \mathrm{L}, 10 \mu \mathrm{L}$ of TaqMan RT buffer, $25 \mathrm{mM} \mathrm{MgCl}, 20 \mu \mathrm{L}$ of deoxyribonucleotide triphosphates (dNTP), $2.5 \mu M$ random hexamers, $0.4 \mathrm{U}$ of RNase inhibitor $/ \mu \mathrm{L}$, and $50 \mu M$ dNTP. The mixture was incubated in a Thermo Hybaid PCR Express thermal cycler (Midwest Scientific, St. Louis MO) at $25^{\circ} \mathrm{C}$ for $10 \mathrm{~min}$, followed by $48^{\circ} \mathrm{C}$ for $30 \mathrm{~min}$, and finally $95^{\circ} \mathrm{C}$ for $5 \mathrm{~min}$. The final mixture was stored at $-80^{\circ} \mathrm{C}$ until further amplified.

Five microliters of the diluted cDNA sample $(0.1 \mu \mathrm{g} /$ $\mathrm{mL}$ ) from reverse transcription was placed in a 96-well plate with $4.5 \mu \mathrm{L}$ of $900 \mathrm{n} M$ primers, $3.25 \mu \mathrm{L}$ of 250 $\mathrm{n} M$ TaqMan MGB probe, $25 \mu \mathrm{L}$ of of PCR Master Mix (Applied Biosystems Inc.), and water to a final volume of $50 \mu \mathrm{L}$. Samples were incubated at $50^{\circ} \mathrm{C}$ for $2 \mathrm{~min}$ and then heated at $95^{\circ} \mathrm{C}$ for $10 \mathrm{~min}$, followed by 40 cycles of $15 \mathrm{~s}$ at $95^{\circ} \mathrm{C}$ and $60 \mathrm{~s}$ at $60^{\circ} \mathrm{C}$. The samples and standards were analyzed using bovine-specific primers and probes to determine expression of IL-1, IL-1 receptor antagonist (Ra), IL-12, IFN- $\gamma$, B-cell transforming gene 1 (BTG1), and TAC1 expression using an ABI Prism 7000 sequence detection system (Applied Biosystems Inc.). All qRT-PCR reactions were performed in duplicate using template from individual animals in each reaction. Relative standard curves were generated by serial dilution of a sample with abundant expression for each gene. Gene qualities were recorded as a ratio of the gene of interest to that of the $18 \mathrm{~S}$ internal standard (Applied Biosystems Inc.). The standard curve was constructed using the following dilutions of cDNA (in triplicate): $1,0.5,0.25,0.125,0.0625$, and 0.0315. A single control sample was selected to be used as the template for the standard curve. Quantitative RT-PCR was performed and analyzed using an ABI Prism 7000 sequence detection system (Applied Biosciences Inc.). Primer and probe sequences for qRTPCR were designed using Primer Express 1.1 software (Applied Biosystems Inc.) and synthesized by Applied Biosystems Inc. (Table 1). Probes were labeled with VIC fluorescent dye.

\section{Statistical Analysis}

Data were analyzed as a randomized complete block design. Replication (fall or spring) was used as the blocking factor. Treatment, time, and their interac- 


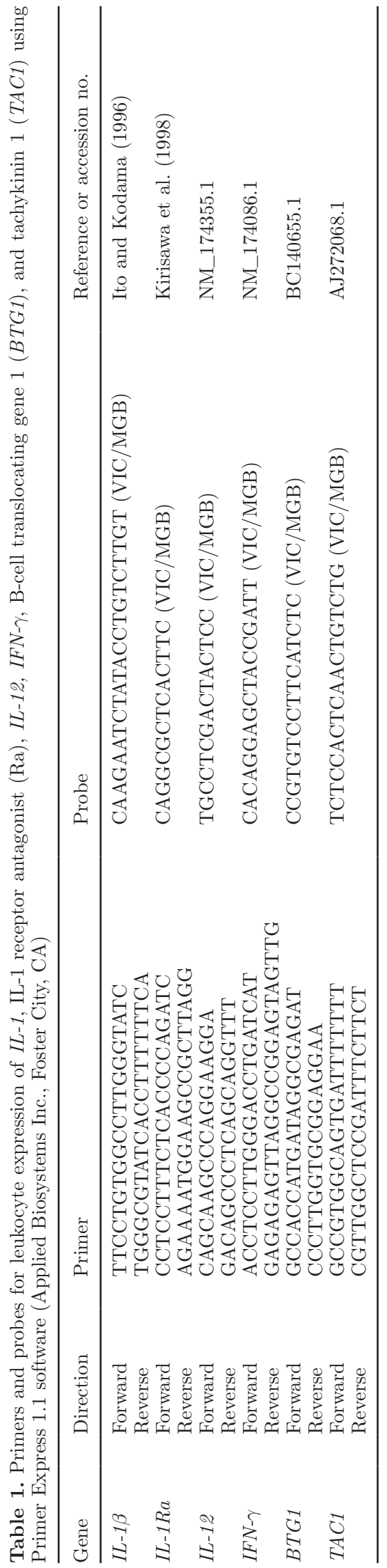

tions were tested as fixed effects. Data were tested for normality and logarithm base 10 transformation was used as noted.

Chi-squared analysis was used to determine the probability of differences between the treatments for calving scores. Effect of RUB compared with CON on number of inseminations and number of days open were analyzed for first parity using PROC GLM of SAS (SAS Institute Inc., Cary, NC), with year-season of first calving (5 consecutive 3-mo seasons) and age at calving $(<24 \mathrm{mo}, 24 \mathrm{mo}$, and $>24 \mathrm{mo})$ fit as an explanatory variables. Effect of RUB compared with CON on MEQ milk, MEQ fat, MEQ protein, fat and protein percentage, and persistency during first lactation were analyzed using PROC GLM of SAS (SAS Institute Inc.), with year-season of first calving (5 consecutive 3 -mo seasons), age at calving (3 classes), and covariates of days open and lactation length in days fit as an explanatory variables. Effect of RUB compared with CON on SCS during first lactation was analyzed using PROC GLM of SAS, with year-season of first calving (5 consecutive 3 -mo seasons), age at calving (3 classes), and covariates of days open and lactation length in days (linear and quadratic) fit as explanatory variables.

\section{RESULTS}

\section{Production and Health}

Rubber flooring increased MEQ milk fat $(P=0.022)$, milk protein $(P=0.009)$, and protein percentage $(P$ $=0.015$ ) during the first lactation (Table 2 ). However, milk yield $(P=0.25)$ and fat percentage $(P=0.11)$ were not affected by treatment. Additionally, persistence $(P=0.17)$, SCC score $(P=0.16)$, days open $(P$ $=0.944)$, and breedings $(P=0.37)$ were similar for rubber- and concrete-housed heifers. Body weight only had an effect of day $(P=0.001)$, with no treatment effect $(P=0.50)$ and no treatment $\times$ day $(P=0.97)$ interaction (data not shown). Injury and disease were infrequent and, therefore, could not be analyzed. The study began with a group of 25 cows within the first 2 mo (January and February expected calving dates). Three were removed from the experiment before they calved ( 1 lame on d 0, 1 aborted $\mathrm{d}-30$, and 1 was not on the technicians' calendar and was missed). A second group of 8 was added in August, with 1 with bad feed at the first foot inspection who was then deleted from the study. Two cows with calving paralysis from concrete flooring were culled. One cow from the concrete group had a dislocated hip and was culled. One cow on concrete flooring had mammalitis and 2 cows on rubber flooring had mastitis. All 3 of those cows were culled. 
Table 2. Significance levels ( $P$-values) for effects of flooring with concrete or rubber flooring in front of the feed bunk and year-season of calving (YS) on measures of milk production, composition, reproduction, and longevity and LSM for floor type during the first parity ${ }^{1}$

\begin{tabular}{|c|c|c|c|c|}
\hline \multirow[b]{2}{*}{ Item } & \multicolumn{2}{|c|}{$P$-value } & \multicolumn{2}{|c|}{ LSM } \\
\hline & Floor & YS & Concrete & Rubber \\
\hline No./treatment & - & - & 12 & 17 \\
\hline \multicolumn{5}{|l|}{ Trait } \\
\hline MEQ milk, ${ }^{2} \mathrm{~kg}$ & 0.252 & 0.162 & $11,593 \pm 498$ & $12,225 \pm 380$ \\
\hline MEQ fat, $\mathrm{kg}$ & $0.022^{*}$ & $0.052 \dagger$ & $432.3 \pm 21.13$ & $488.4 \pm 16.15$ \\
\hline MEQ protein, $\mathrm{kg}$ & $0.009^{*}$ & $0.067 \dagger$ & $326.1 \pm 12.44$ & $364.4 \pm 9.50$ \\
\hline Fat percentage & 0.108 & 0.510 & $3.7 \pm 0.17$ & $4.0 \pm 0.13$ \\
\hline Protein percentage & $0.015^{*}$ & 0.707 & $2.8 \pm 0.07$ & $3.0 \pm 0.05$ \\
\hline Persistency $^{3}$ & 0.173 & 0.344 & $113.7 \pm 2.91$ & $109.1 \pm 1.76$ \\
\hline SCC & 0.164 & 0.703 & $2.6 \pm 0.66$ & $1.4 \pm 0.52$ \\
\hline Days open & 0.941 & 0.012 & $135.0 \pm 20.23$ & $133.3 \pm 15.55$ \\
\hline Breedings, no. & 0.371 & 0.005 & $2.8 \pm 0.43$ & $2.3 \pm 0.30$ \\
\hline Herd life, ${ }^{4} \mathrm{~d}$ & 0.337 & 0.197 & $789.6 \pm 25.18$ & $966.0 \pm 19.20$ \\
\hline
\end{tabular}

\section{Hoof Scores}

The number of therapy treatments per cow (Table $3)$ were greater $(P=0.03)$ for concrete compared with rubber housed cows. Therapy consisted of topical antibiotic application and wrapping as appropriate. The percentage of cows that received hoof therapy was not different between treatments $(P=0.13)$ as was the number of hooves that were treated $(P=0.13)$. The mean lactation year of first hoof treatment $(P=$ $0.61)$, minimum severity $(P=0.56)$, and maximum severity $(P=0.28)$ were not different between treatments.

\section{Locomotion Scores}

Locomotion total scores (Figure 1; Table 4) were worse (greater) for cows housed on concrete during the second lactation (treatment $\times$ day: $P<0.001$ ). Except for the variable speed, the other locomotion variables had a treatment $\times$ day interaction $(P<0.025)$.

\section{Cortisol}

During the first lactation, a treatment by time interaction indicated that cows on concrete tended to have had greater concentrations of cortisol $(P<0.10)$

Table 3. Hoof evaluations and therapies for conditions that lead to lameness for cows housed on concrete or rubber flooring

\begin{tabular}{|c|c|c|c|c|c|c|c|}
\hline \multirow[b]{2}{*}{ Item } & \multirow[b]{2}{*}{$\begin{array}{c}\text { Concrete } \\
\text { floor }\end{array}$} & \multirow[b]{2}{*}{$\begin{array}{l}\text { Rubber } \\
\text { floor }\end{array}$} & \multirow[b]{2}{*}{$P$-value } & \multicolumn{2}{|c|}{$\operatorname{yr} 1^{1}$} & \multicolumn{2}{|c|}{$\operatorname{yr} 2^{1}$} \\
\hline & & & & Concrete & Rubber & Concrete & Rubber \\
\hline \multicolumn{8}{|l|}{ Variable } \\
\hline Therapy, \% of cows & 50 & 22 & 0.13 & & & & \\
\hline Lactation, year of first treatment & 1.5 & 1.39 & 0.61 & & & & \\
\hline Therapy, no. per cows & 2.19 & 1.44 & 0.03 & & & & \\
\hline Hooves, no. treated per cow & 3.38 & 2.61 & 0.13 & & & & \\
\hline Mean minimum severity ${ }^{2}$ & 1.13 & 1.06 & 0.56 & & & & \\
\hline Mean maximum severity ${ }^{2}$ & 2.00 & 1.61 & 0.28 & & & & \\
\hline \multicolumn{8}{|l|}{ Condition/diagnosis, no. of cows } \\
\hline Digital dermatitis & & & & $\begin{array}{c}2(1) ; 2(2) ; \\
3(3) ; \text { total }=7\end{array}$ & $\begin{array}{c}1(1) ; 2(2) ; \\
1(3) ; \text { total }=4\end{array}$ & $2(3)$ & $1(1) ; 1(2)$ \\
\hline Foot rot & & & & 9 & 9 & 7 & 2 \\
\hline Abscess & & & & 1 & 0 & $\begin{array}{c}1 ; 1(3) ; \\
\text { total }=2\end{array}$ & 0 \\
\hline Sole ulcer & & & & 1 & 2 & 2 & 2 \\
\hline Sole separation & & & & 6 & 1 & 3 & 0 \\
\hline
\end{tabular}

${ }^{1}$ Numbers in parentheses denote severity: $1=$ not requiring treatment; $2=$ more than 1 tissue involved; $3=$ severe.

${ }^{2}$ Degree of tissue involved (Shearer et al., 2004). 
Table 4. Probability of differences for locomotion variables and total locomotion score for cows housed on concrete or rubber flooring using the scoring of O'Callaghan et al. (2003) and Sprecher et al. (1997)

\begin{tabular}{lcll}
\hline $\begin{array}{l}\text { Locomotion } \\
\text { variable }\end{array}$ & Day & Floor & $\begin{array}{l}\text { Floor } \\
\times \text { day }\end{array}$ \\
\hline Total & 0.0001 & 0.13 & 0.0001 \\
Head bob & 0.0001 & 0.473 & 0.0001 \\
Back arch & 0.0001 & 0.523 & 0.005 \\
Tracking & 0.0001 & 0.046 & 0.025 \\
Rotation & 0.0001 & 0.040 & 0.0001 \\
Speed & 0.0001 & 0.2035 & 0.185 \\
\hline
\end{tabular}

during the seventh, eighth, and tenth week (Figure 2). In contrast, cortisol concentrations were much lower in the second lactation and did not differ by treatment (Figure 2; $P>0.10$ ).

\section{Hematology}

Total white blood cell counts (Figure 3) began at similar concentrations during the first 10 wk of lactation 1. Cows housed on concrete then had greater WBC counts after the first 10 wk of lactation until they were housed on the bedded packs during dry off (treatment $\times$ time effect: $P=0.001$; treatment effect: $P=0.045$; day effect: $P=0.001$ ). Within the first 2 wk after cows were returned to their treatment floors, those on concrete had greater WBC counts that remained greater throughout 26 wk of that lactation when the study was completed. The greater leukocyte counts for the cows housed on concrete were caused by increased lymphocytes (Figure 3 ; treatment $\times$ time effect: $P=0.001$ ).

\section{Gene Expression}

The leukocyte gene expression (Figure 4) of IL-1 $\beta$ was greater $(P=0.024)$ and IL-1Ra was less $(P=$ $0.004)$ for cows housed entirely on concrete. The other 2 cytokines, IFN- $\gamma$ and IL-12, were not different $(P>$ $0.10)$ between the treatments. The B-cell translocation gene 1 and TAC1 were not different $(P>0.10)$ between the treatments at this time (d 90 of the second lactation).

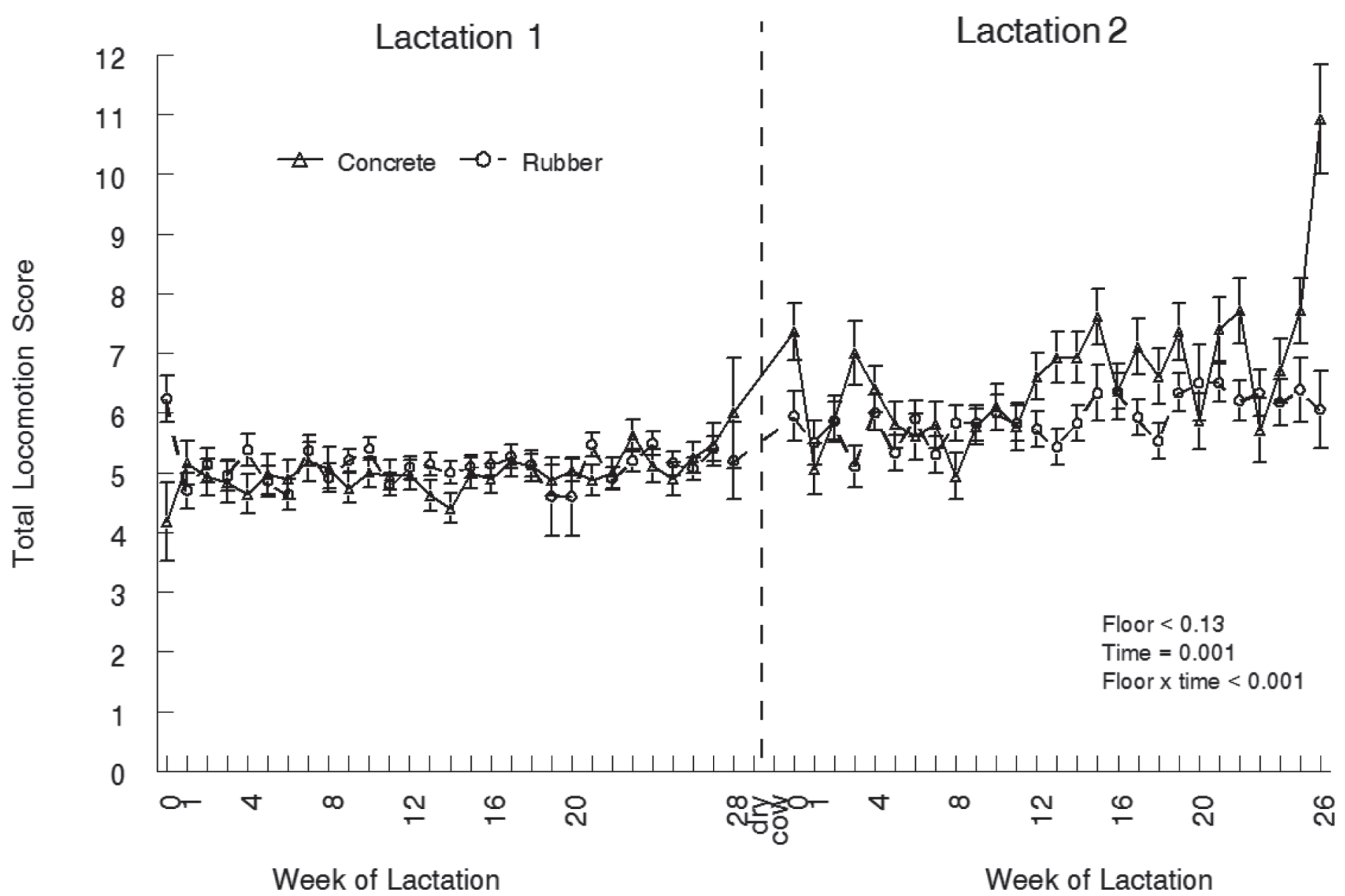

Figure 1. Total locomotion scores from wk 0 to 26 during each of the first and second lactations (LSM \pm SE). $P$-values for different effects are given in the lower right part of the figure. 


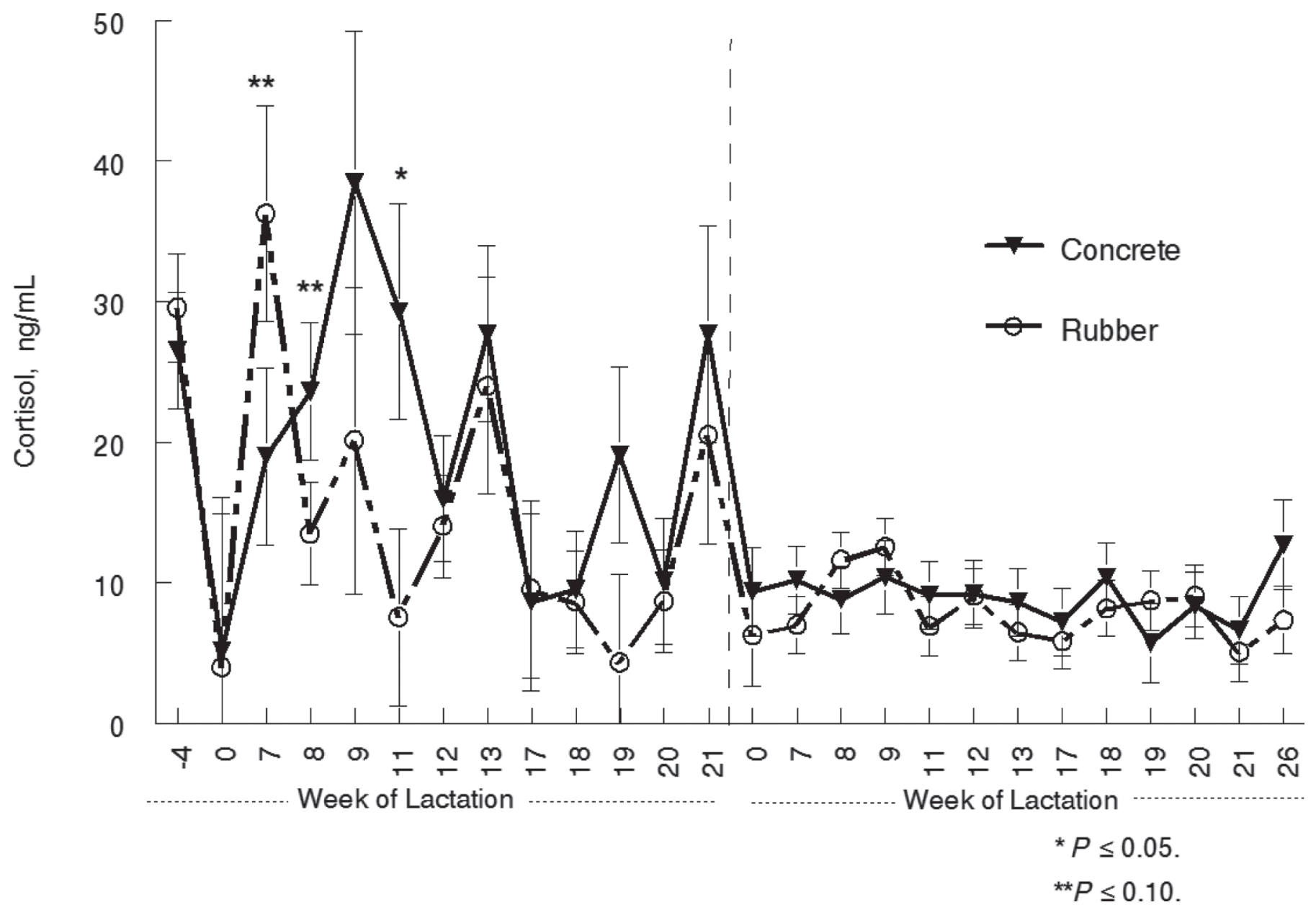

Figure 2. Mean cortisol concentrations over the first and second lactations of cows housed on concrete or rubber (LSM \pm SE).

\section{Acute-Phase Proteins}

The acute-phase proteins (Figure 5), haptoglobin (treatment $\times$ week: $P=0.15$ ), and ceruloplasmin (week: $P=0.08$ ), did not show treatment differences during the first lactation. Fibrinogen had a treatment by week $(P=0.03)$ effect such that concentrations were greater for cows housed on concrete at wk 8 of the first lactation, but were similar throughout the remainder of the lactation.

\section{DISCUSSION}

\section{Cow Comfort, Lameness, and Locomotion}

Rubber flooring is used to improve cow comfort in freestall housing and holding areas (Cook and Nordlund, 2009). Multiple researchers have concluded that soft flooring surfaces (such as rubber) are beneficial for hoof health (Vanegas et al., 2006). Cows on rub- ber have shown greater activity (Kremer et al., 2007) and have shown a preference for standing and walking on rubber than on concrete flooring (Telezhenko et al., 2007). Additionally, rubber flooring was thought to provide a more secure footing and was more comfortable to walk on, especially for lame cows (Flower et al., 2007). Earlier, Rushen and de Passillé (2006) found that rubber flooring improved locomotion compared with those on concrete flooring. This may be caused by changes in claw conformation (Telezhenko et al., 2009) and altered claw growth (Vanegas et al., 2006). Rubber flooring resulted in fewer therapy treatments for cows in our study. The second-lactation cows that were housed on concrete had pronounced locomotion score changes. However, all parts (with the exception of speed) of the locomotion scoring had significant treatment by time interactions. Head bob and back arch maintained treatment effects throughout. Using kinematic gait analysis, Flower et al. (2007) showed 

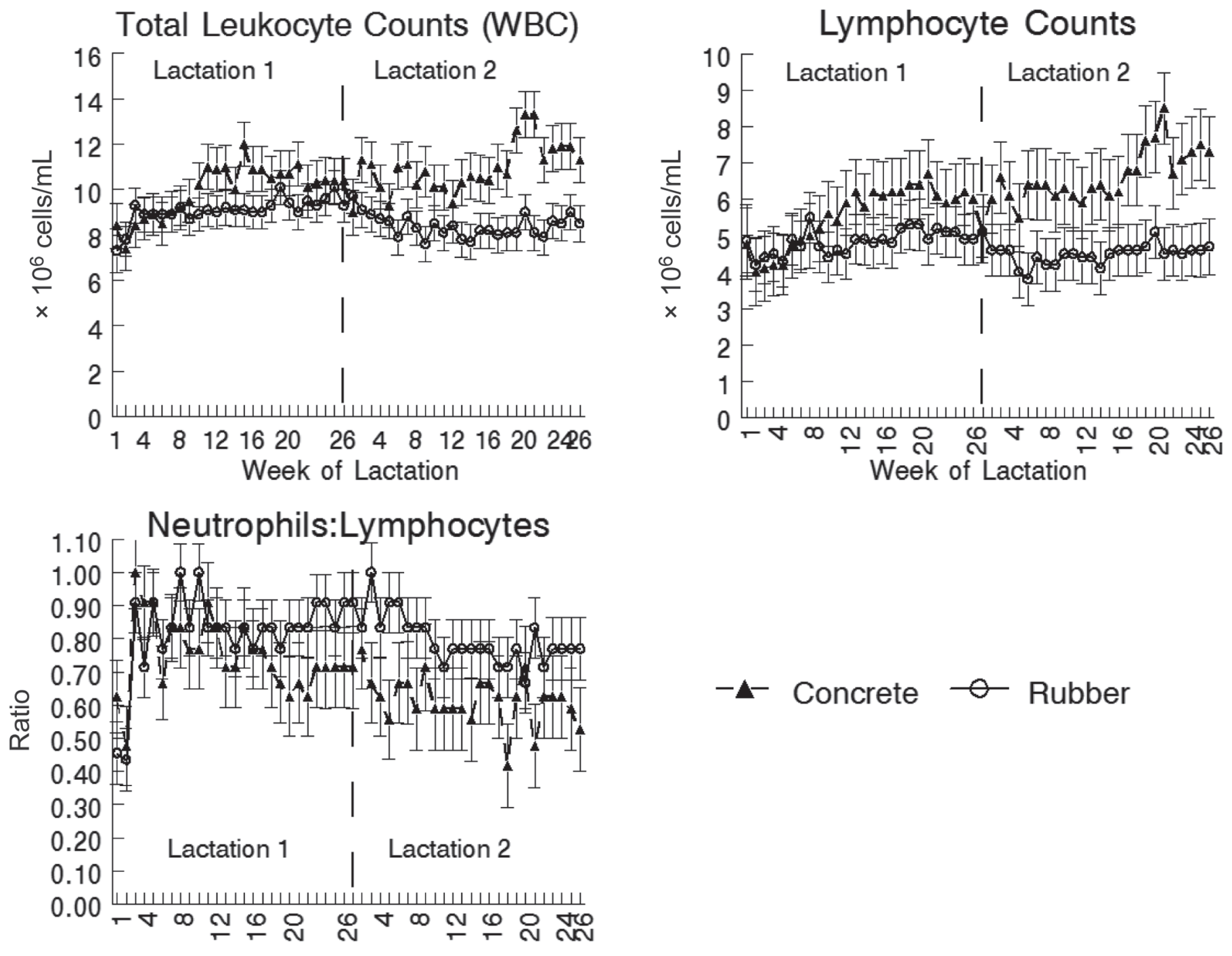

\section{Week of Lactation}

Figure 3. Counts of total leukocytes, lymphocytes, and the neutrophil-to-lymphocyte ratio of cows housed on concrete or rubber (LSM \pm $\mathrm{SE})$. The first $26 \mathrm{wk}$ of first and second lactations are shown. The dashed line designates the end of the first lactation. WBC $=$ white blood cells.

greater stride length, height, overlap, swing duration, and greater speed for cows with sole ulcers on rubber than for those on concrete corridors. The current study used a rubber over concrete corridor for scoring locomotion for cows that were from both treatments. Cows were acclimated to rubber because all cows also had rubber available to walk on between the freestall area and the holding pens of the parlor. Therefore, our locomotion scores assessed residual changes caused by their freestall housing, rather than immediate responses to the walking surface.

\section{Production}

Rubber flooring did not alter overall milk yield (Kremer et al., 2007). Our results did not point to signifi- cant changes in overall lactation milk yield. The milk fat and protein and protein percentage, which contribute to economic gains, were all improved with rubber flooring. Lameness and milk production are negatively associated (Warnick et al., 2001) and this was demonstrated again in 2008 (Bicalho et al., 2008). Production variables (growth and milk yield) frequently require a greater number of animals to demonstrate changes. Additionally, the degree of lost milk production depends on the etiology of the lameness.

\section{Stress and Hematology}

Cows housed on concrete during the first lactation tended to be in more pain and (or) be more stressed, as 


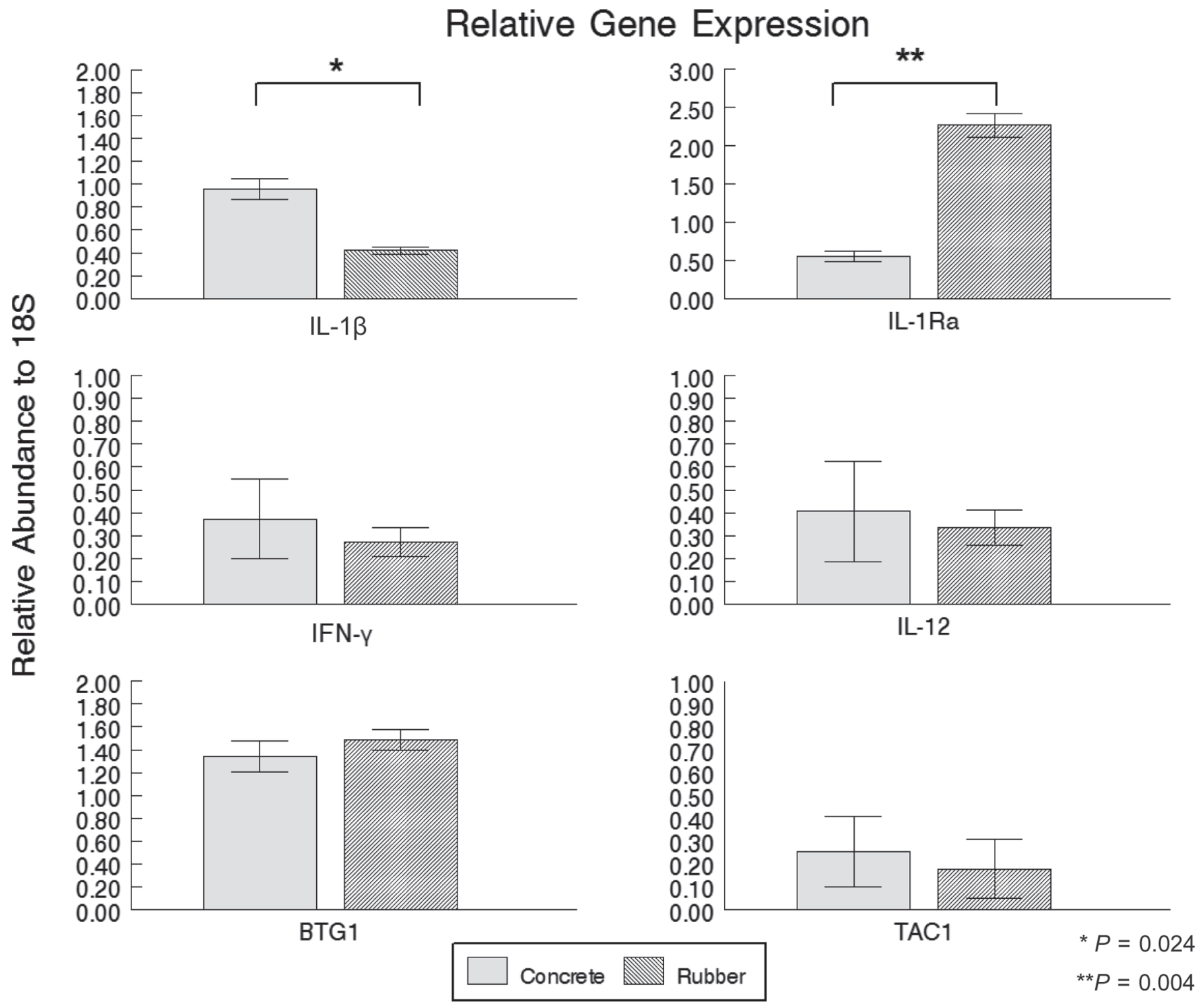

Figure 4. Relative abundance of IL-1, IL-1 receptor antagonist (Ra), IFN- $\gamma$, IL-12, B-cell transforming gene 1 (BTG1), and tachykinin 1 (TAC1) in leukocytes at $d 140$ of the second lactation (LSM $\pm \mathrm{SE})$.

evidenced by tendencies to have greater cortisol concentrations at several points during the first lactation. It is well known that animals exposed to an acute stressor exhibit increased concentrations of cortisol. It is also true that animals subjected to painful procedures also have an increase in cortisol (Lay et al., 1992; Stafford and Mellor, 2005; Stewart et al., 2010). The cortisol responses appear to peak at similar times during the first lactation. Thus, these cortisol data could indicate either pain or stress, which are inextricable without consideration of other types of data. The great variability in cortisol concentrations indicates difficulty to adjust to the first lactation for cows in both treatments. This is in sharp contrast to the second lactation in which cows in both treatments exhibited considerably reduced concentrations of cortisol, indicative of an animal that has adapted to its environment. Riva et al. (2012) showed cortisol responses for humans with shoulder and neck pain (regional pain) were greater than for people with fibromyalgia (widespread pain). The authors suggested that the hypercortisol responses in the regional pain condition represent an intermediate stage toward development of hypocortisol responses in widespread pain such as fibromyalgia. This may partially explain the equivalent cortisol responses in the second lactation of the current study. Chronic social stress of dairy calves 

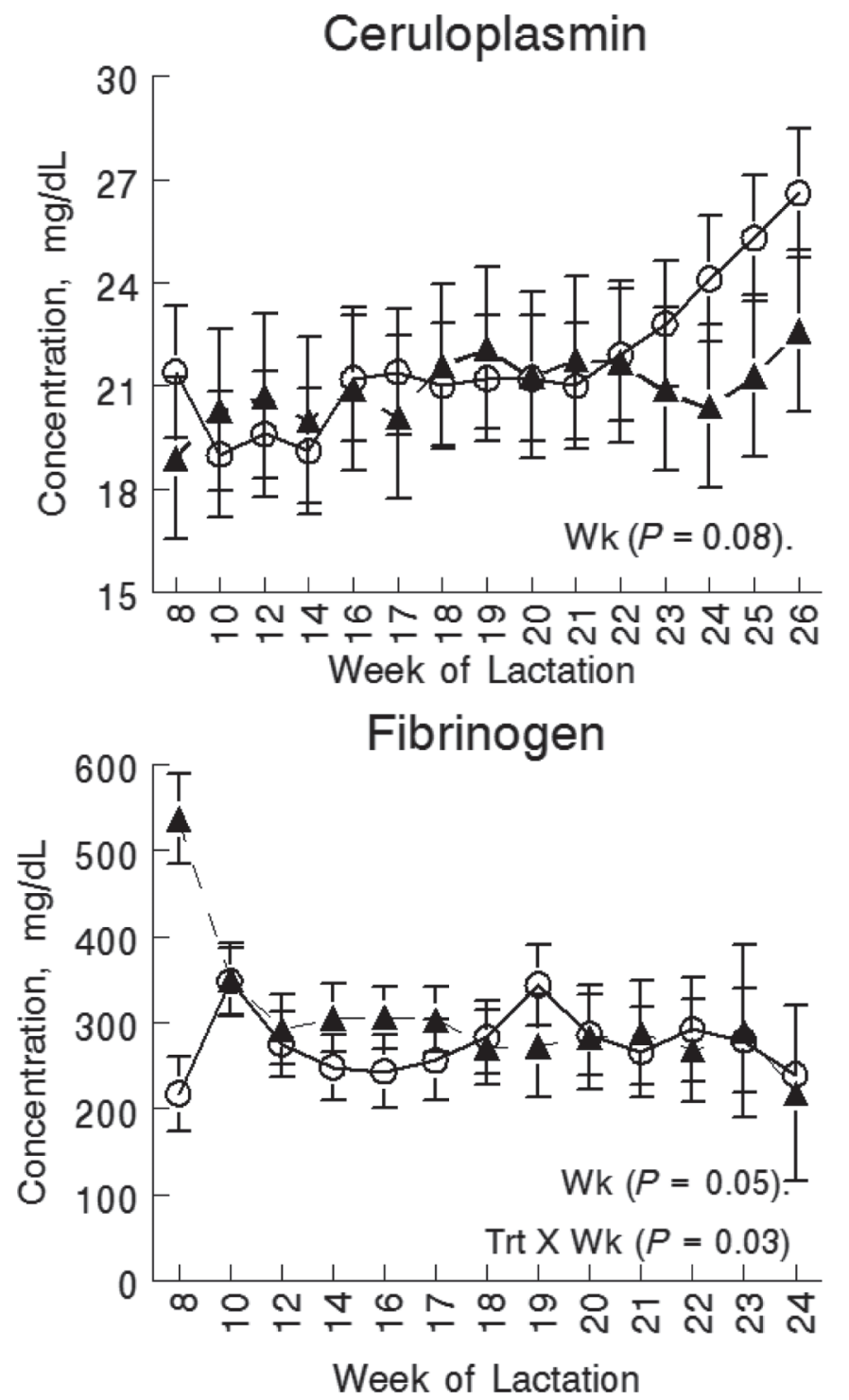

\section{Haptoglobin}

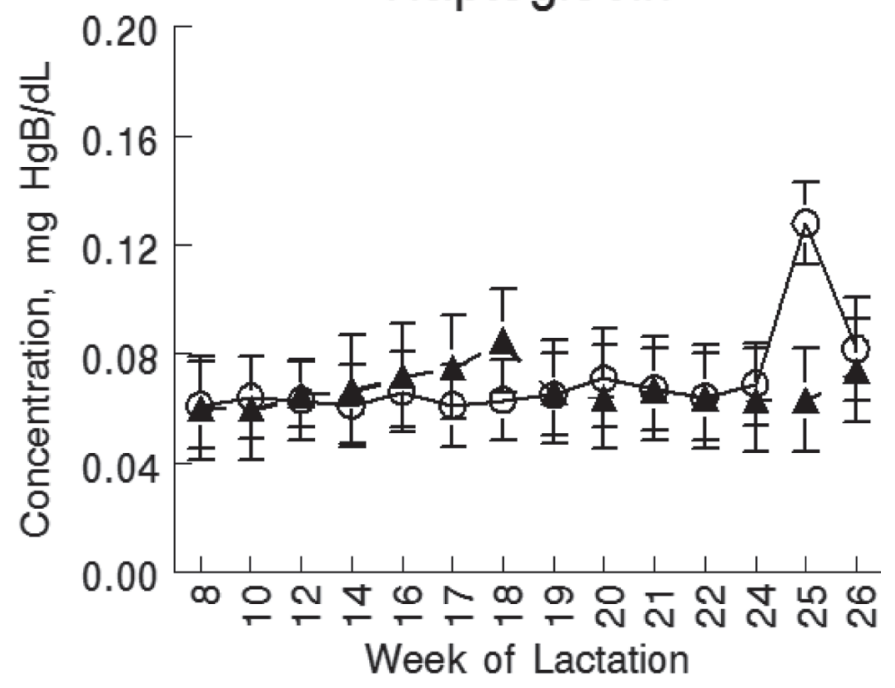

$-\boldsymbol{\Delta}$ - Concrete 0 Rubber

Figure 5. Concentrations of acute-phase proteins, ceruloplasmin, haptoglobin, and fibrinogen for the first lactation (wk 0 through 26 ) of cows housed on concrete or rubber $(\mathrm{LSM} \pm \mathrm{SE}) . \mathrm{Wk}=$ week; $\mathrm{Trt}=$ treatment.

(C. S. Wilcox, Purdue University, West Lafayette, IN; unpublished data) resulted in an inability to respond to adrenocorticotropic hormone and, thus, lower cortisol response (adrenal fatigue). Therefore, an adrenocorticotropic hormone response test would be necessary to determine if the lack of response during the second lactation of the cows on concrete was due to reduced stress or adrenal fatigue. However, because of the reduced responses of all cows, habituation to the housing and milking environments is the most probable explanation.

The inflammatory cytokine IL-6 and cortisol both increased (Geiss et al., 2012) with a pressure pain test for people with fibromyalgia (chronic pain). The IL-6 response appears similar to the greater IL-1 mRNA expression we observed with concrete-housed cows. In this light, the IL-1 mRNA expression and lymphocyte counts of the current study indicate that these cows had inflammation in the second lactation, which is commonly associated with pain. Additionally, this is the same point in time that locomotion scores began to differ between the cows housed on rubber and those housed on concrete. If the increased mononuclear cells are primarily monocytes or macrophages, this would also explain the increase in mRNA for IL-1 by changing cell populations alone. The cows housed on concrete had more incidence of foot rot during the second lactation, which could be associated with the greater cell counts and IL-1 expression in the second lactation. The 
APP did not reflect changes that were evident in the cell populations at the end of the first lactation.

The worsened locomotion scores in the second lactation and the greater total white blood cell counts, point to a heightened response of cows to returning to the concrete flooring. The impact of lameness is life long, even when treated successfully (Laven et al., 2008). To our knowledge, no one has investigated the effects of flooring on either the stress or inflammatory responses. However, Almeida et al. (2007) reported gene expression changes based on lame cows (foot lesions) compared with apparently sound cows. Their samples were from peripheral blood mononuclear cells and suggested changes related to tissue regeneration and inflammation.

\section{Chronic Pain and Inflammation Indications}

The upregulated genes in lame cows were $I L$-2, metalloproteinase-13 (MMP-13), and chemokine $\mathrm{C}-\mathrm{C}$ motif receptor 5 (CCR5; Almeida et al., 2007). The proinflammatory cytokine granulocyte-macrophage colony-stimulating factor receptor $\alpha$ chain precursor (GMCSF-R- $\alpha$ ) tended to be greater for lame cows, as did the antiinflammatory cytokines IL-10 and IL-4 in that study. The current study showed significant increased inflammatory cytokine (IL-1) and greatly reduced mRNA expression of its receptor antagonist for cows on concrete. Although the Almeida et al. (2007) study was strictly about hoof lesion lameness compared with sound cows and ours was a comparison of responses to rubber or concrete flooring, both suggest that inflammation is evident by gene analysis of blood leukocytes.

Acute-phase protein responses appeared to be in response to more immediate events than the chronic stress of flooring, with the exception of ceruloplasmin, which nonsignificantly appeared to be increasing during the later weeks of the current study for cows with access to rubber flooring. Smith et al. (2010) reported increased serum haptoglobin within $3 \mathrm{~d}$ after lameness was observed, which is typical of an acute stressor. However, cows with evidence of chronic inflammation had greater ceruloplasmin and haptoglobin responses following parturition (Bossaert et al., 2012) and greater concentrations of ceruloplasmin are associated with chronic inflammation (Shyni et al., 2010). However, ceruloplasmin has both anti- and pro-oxidant activities (Marques et al., 2012) and is believed to be essential to many biochemical process (Vasilyev, 2010). Marques et al. (2012) found that in macrophages, one form of ceruloplasmin likely interacts with ferroportin in lipid rafts to export iron from cells. Those authors further defined the subcellular localization of ceruloplasmin in monocytes. Additional clarification of the isoform of ceruloplasmin is needed to determine its role in iron metabolism during inflammation and chronic inflammation and potentially to differentiate the 2 conditions.

\section{CONCLUSIONS}

The results of this study showed that going into the second lactation, chronic inflammation, indicated by greater IL-1 and lymphocyte numbers, is activated after being on the less harsh pasture and bedded-pack flooring. Because of the multiple cell populations and functions within the peripheral blood lymphocytes, further analysis is needed to determine which lymphocyte populations increased. The samples analyzed here are only from d 140 of the second lactation; further analysis of cells closer to parturition would be of interest to determine which cytokines or chemokines are expressed as the inflammation begins or resumes. Also, early in the second lactation may be a better time to investigate the TAC1 gene expression to allow us to begin to unravel the pain and inflammation relationship in dairy cattle. The interaction of the neurological and immunological systems is quite complex and appears to happen at the peripheral level as well as in the brain and central nervous system. Peripheral blood cells may harbor a useful biomarker of chronic pain in cattle.

\section{REFERENCES}

Alawneh, J. I., R. A. Laven, and M. A. Stevenson. 2012a. Interval between detection of lameness by locomotion scoring and treatment for lameness: A survival analysis. Vet. J. 193:622-625.

Alawneh, J. I., M. A. Stevenson, N. B. Williamson, N. Lopez-Villalobos, and T. Otley. 2012b. The effect of clinical lameness on liveweight in a seasonally calving, pasture-fed dairy herd. J. Dairy Sci. 95:663-669.

Almeida, P. E., P. S. D. Weber, J. L. Burton, R. J. Tempelman, J. P. Steibel, and A. J. Zanella. 2007. Gene expression profiling of peripheral mononuclear cells in lame dairy cows with foot lesions. Vet. Immunol. Immunopathol. 120:234-245.

Bicalho, R. C., V. S. Machado, and L. S. Caixeta. 2009. Lameness in dairy cattle: A debilitating disease or a disease of debilitated cattle? A cross-sectional study of lameness prevalence and thickness of the digital cushion. J. Dairy Sci. 92:3175-3184.

Bicalho, R. C., L. D. Warnick, and C. L. Guard. 2008. Strategies to analyzed milk losses caused by diseases with potential incidence throughout the lactation: A lameness example. J. Dairy Sci. 91:2653-2661

Booth, C. J., L. D. Warnick, and Y. T. Gröhn. 2004. Effect of lameness on culling in dairy cows. J. Dairy Sci. 87:4115-4122.

Bossaert, P., E. Trevisi, G. Opsomer, G. Bertoni, S. De Vliegher, and J. L. M. R. Leroy. 2012. The association between indicators of inflammation and liver variables during the transition period in highyielding dairy cows: An observational study. Vet. J. 192:222-225.

Boyle, L. A., J. F. Mee, and P. J. Kiernan. 2007. The effect of rubber versus concrete passageways in cubicle housing on claw health and reproduction of pluriparous dairy cows. Appl. Anim. Behav. Sci. 106:1-12.

Calderon, D. F., and N. B. Cook. 2011. The effect of lameness on the resting behavior and metabolic status of dairy cattle during the transition period in a freestall-housed dairy herd. J. Dairy Sci. 94:2883-2894. 
Cha, E., J. A. Hertl, D. Bar, and Y. T. Gröhn. 2010. The cost of different types of lameness in dairy cows calculated by dynamic programming. Prev. Vet. Med. 97:1-8.

Cook, N. B., and K. V. Nordlund. 2009. The influence of the environment on dairy cow behavior, claw health and herd lameness dynamics. Vet. J. 179:360-369.

Demetriou, J. A., P. A. Drewes, and J. B. Gin. 1974. Ceruloplasmin. Pages 857-864 in Clinical Chemistry: Principles and Techniques. 2nd ed. R. J. Henry, D. C. Cannon, and J. W. Winkelman, ed. Harper and Row, Hagerstown, MD.

Espejo, L. A., and M. I. Endres. 2007. Herd-level risk factors for lameness in high-producing Holstein cows housed in freestall barns. J. Dairy Sci. 90:306-314.

Espejo, L. A., M. I. Endres, and J. A. Salfer. 2006. Prevalence of lameness in high-producing Holstein cows housed in freestall barns in Minnesota. J. Dairy Sci. 89:3052-3058.

Flower, F. C., A. M. de Passillé, D. M. Weary, D. J. Sanderson, and J. Rushen. 2007. Softer, higher-friction flooring improves gait of cows with and without sole ulcers. J. Dairy Sci. 90:1235-1242.

Geiss, A., N. Rohleder, and F. Anton. 2012. Evidence for an association between an enhanced reactivity of interleukin-6 levels and reduced glucocorticoid sensitivity in patients with fibromyalgia. Psychoneuroendocrinology 37:671-684.

Haskell, M. J., L. J. Rennie, V. A. Bowell, M. J. Bell, and A. B. Lawrence. 2006. Housing system, milk production, and zero-grazing effects on lameness and leg injury in dairy cows. J. Dairy Sci. 89:4259-4266.

Ito, T., and M. Kodama. 1996. Demonstration by reverse transcription-polymerase chain reaction of multiple cytokine mRNA expression in bovine alveolar macrophages and peripheral blood mononuclear cells. Res. Vet. Sci. 60:94-96.

King, J. 1965. Ceruloplasmin. Pages 108-110 in Practical Clinical Enzymology. Van Nostrand, London, UK.

Kirisawa, R., T. Fukuda, H. Yamanaka, K. Hagiwara, M. Goto, Y. Obata, T. Yoshino, and H. Iwai. 1998. Enzymatic amplification and expression of bovine interleukin-1 receptor antagonist cDNA. Vet. Immunol. Immunopathol. 62:197-208.

Kremer, P. V., S. Nueske, A. M. Scholz, and M. Foerster. 2007. Comparison of claw health and milk yield in dairy cows on elastic or concrete flooring. J. Dairy Sci. 90:4603-4611.

Laven, R. A., K. E. Lawrence, J. F. Weston, K. R. Dowson, and K. J. Stafford. 2008. Assessment of the duration of the pain response associated with lameness in dairy cows, and the influence of treatment. N. Z. Vet. J. 56:210-217.

Lay, D. C. Jr., T. H. Friend, C. L. Bowers, K. K. Grissom, and O. C. Jenkins. 1992. A comparative physiological and behavioral study of freeze and hot-iron branding using dairy cows. J. Anim. Sci. 70:1121-1125.

Main, D. C. J., K. A. Leach, Z. E. Barker, A. K. Sedgwick, C. M. Maggs, N. J. Bell, and H. R. Whay. 2012. Evaluating an intervention to reduce lameness in dairy cattle. J. Dairy Sci. 95:29462954.

Makimura, S., and N. Suzuki. 1982. Quantitative determination of bovine serum haptoglobin and its elevation in some inflammatory diseases. Jpn. J. Vet. Sci. 44:15-21.

Marques, L., A. Auriac, A. Willemetz, J. Banha, B. Silva, R. CanonneHergaux, and L. Costa. 2012. Immune cells and hepatocytes ex- press glycosylphosphatidylinositol-anchored ceruloplasmin at their cell surface. Blood Cells Mol. Dis. 48:110-120.

O'Callaghan, K. A., P. J. Cripps, D. Y. Downham, and R. D. Murray. 2003. Subjective and objective assessment of pain and discomfort due to lameness in dairy cattle. Anim. Welf. 12:605-610.

O'Driscoll, K. K. M., M. M. Schutz, A. C. Lossie, and S. D. Eicher. 2009. The effect of floor surface on dairy cow immune function and locomotion score. J. Dairy Sci. 92:4249-4261.

Riva, R., P. J. Mork, R. H. Westgaard, and U. Lundberg. 2012. Comparison of the cortisol awakening response in women with shoulder and neck pain and women with fibromyalgia. Psychoneuroendocrinology 37:299-306.

Rushen, J., and A. M. de Passillé. 2006. Effects of roughness and compressibility of flooring on cow locomotion. J. Dairy Sci. 89:29652972.

Shearer, J. K., D. Anderson, W. Ayers, E. Bellknap, S. Berry, C. Guard, K. Hoblet, E. Hovingh, G. Kirksey, A. Langhill, A. Mills, D. Miskimens, J. Osterstock, R. Price, D. Prigel, A. Roussel, S. R. Van Amstel, R. Wallace, J. Wasson, N. Cook, E. Garrett, D. Hostetler, and L. A. Schugel. 2004. A record-keeping system for capture of lameness and foot-care information in cattle. Pages 83-92 in The Bovine Practitioner. Vol. 38, No. 1. R. A. Smith, ed. American Association of Bovine Practitioners/Frontier Printers, Stillwater, OK.

Shyni, G. L., M. Ratheesh, G. Sindhu, and A. Helen. 2010. Antiinflammatory and antioxidant effects of Jeevaneeye Rasayana: An ayurvedic polyherbal formulation on acute and chronic models of inflammation. Immunopharmacol. Immunotoxicol. 32:569-575.

Smith, B. I., J. Kauffold, and L. Sherman. 2010. Serum haptoglobin concentrations in dairy cattle with lameness due to claw disorders. Vet. J. 186:162-165.

Sprecher, D. J., D. E. Hostetler, and J. B. Kaneene. 1997. A lameness scoring system that uses posture and gait to predict dairy cattle reproductive performance. Theriogenology 47:1179-1187.

Stafford, K. J., and D. J. Mellor. 2005. The welfare significance of the castration of cattle: A review. N. Z. Vet. J. 53:271-278.

Stewart, M., G. A. Verkerk, K. J. Stafford, A. L. Schaefer, and J. R. Webster. 2010. Noninvasive assessment of autonomic activity for evaluation of pain in calves, using surgical castration as a model. J. Dairy Sci. 93:3602-3609.

Telezhenko, E., C. Bergsten, M. Magnusson, and C. Nilsson. 2009. Effect of different flooring systems on claw conformation of dairy cows. J. Dairy Sci. 92:2625-2633.

Telezhenko, E., L. Lidfors, and C. Bergsten. 2007. Dairy cow preferences for soft or hard flooring when standing or walking. J. Dairy Sci. 90:3716-3724.

Vanegas, J., M. Overton, S. L. Berry, and W. M. Sischo. 2006. Effect of rubber flooring on claw health in lactating dairy cows housed in free-stall barns. J. Dairy Sci. 89:4251-4258.

Vasilyev, V. B. 2010. Interactions of caeruloplasmin with other proteins participating in inflammation. Biochem. Soc. Trans. 38:947-951.

Warnick, L. D., D. Janssen, C. L. Guard, and Y. T. Gröhn. 2001. The effect of lameness on milk production in dairy cows. J. Dairy Sci. 84:1988-1997.

Whay, H. R., A. J. F. Webster, and A. E. Waterman-Pearson. 2005. Role of ketoprofen in the modulation of hyperalgesia associated with lameness in dairy cattle. Vet. Rec. 157:729-733. 